\title{
Organizational Management Cases in Hospitality Businesses in Nueva Ecija: A COVID19 Experiences
}

\author{
Aileen Y. Vigilia
}

College of Management \& Business Technology, Hospitality and Tourism Management Department, Nueva Ecija University of Science \& Technology, Cabanatuan City 3100 Philippine

Received: 11 Nov 2020; Received in revised form: 09 Jan 2021; Accepted: 17 Jan 2021; Available online: 31 Jan 2021 (C)2021 The Author(s). Published by Infogain Publication. This is an open access article under the CC BY license (https://creativecommons.org/licenses/by/4.0/).

\begin{abstract}
The study determined the impact of COVID-19 pandemic in hospitality business management organization in Nueva Ecija. The main respondents of the study are 150 respondents from the hospitality business in Nueva Ecija. A mixed-method research design was utilized to have to support the objective of the study with the used of purposive sampling technique. The results of the study revealed that 100\% of the hospitality businesses and management organization in Nueva Ecija were decided to stop their operation for the meantime upon looking for the alternative ways in supporting the basic needs of their employees and to sustain operations. Almost 97\% were affected and face challenges in managing operation because COVID -19 had great impact they experienced anxiety, stress, financial difficulties and job loss. It is recommended for the hospitality business industry to continuously providing quality services and extra care not only for the employees but also those that they can extend their help to all individuals.
\end{abstract}

Keywords-COVID-19, Hospitality Business, Impact, Management Organization.

\section{INTRODUCTION}

Organizational management is the key aspects that binds the employees, staffs, operators and other members of the organization together and gives them a wisdom and sense of loyalty and appreciation. It is very essential to manage the employees well in an organization for them to feel that they are important and belong to the group they have. The employees and staffs even the manager and owner must work together in a close coordination with each and every one and always try their very best to achieve the organizational goals, mission and vision.

Organization management especially in hospitality businesses enables the optimum use of resources through meticulous planning and control at the work place so that all employees are well aware and inform of their designated roles, tasks and sense of responsibility for the common good that also gives them a sense of security and oneness organization.

The hospitality business is one of the businesses that is much affected in the country's current situation due to the global pandemic of COVID-19. This devastating COVID-19 virus outrageous the economic progress in the whole world.

In the Philippines, the President Rodrigo Duterte ordered to locked all the businesses operation especially in hospitality sectors like bars, restaurants, amusement park, etc. that aimed to help not to spread viruses.
According to Burton \& O'Neill (n.d), the global COVID-19 pandemic has challenged companies to manage their enterprises in the newfound ways. In short term, they are facing enormous scope changes to their business plans, how to adopt and continues to make progress on their original goals. Moreover, organization needs to ensure their business strategies incorporate crisis management disaster recovery and risk management in order to adapt and get back to track to true business effort.

The COVID-19 pandemic has brought in many realities. The ever-evolving hospitality world has received the biggest setback in revenue generation and costs remain high. With travel at its record low, hotels need to remain agile, and they need to be at the forefront to manage different customer groups with a speed that has never been exercised before, (Kapur, 2020).

Almost all of the people around the world stopped their daily activities outside like travelling to other places and countries, going out to mall for shopping, going out to hotel, restaurant and resort for unwind and leisure activities over fears of spreading of COVID-19 and the hospitality sectors was bracing for the severe downturn.

According to Gossling et al., (2020), travel bans, border closures, events cancellation, quarantine requirements and fear of spread, have placed extreme challenges on hospitality industry. 
But due to many factors, more reasons, problems and challenges arises in management of one's organization that truly businesses really affected and experiences economic crisis resulting to income losses, job opportunities and financial difficulties in all aspects.

McCarthy (2020) said that, hospitality industry had never seen the situation like the current pandemic. It is important for the industry to acknowledge that there are no "experts" on this kind of pandemic or situation. Just a group of industry, they are trying their best to figure out how to best navigate a very difficult and very unpredictable situation. He added, as Group Director, he does see a few opportunities to leverage wellness positioning as a way to aid in the recovery.

In this notion the researcher, aims to find out the challenges facing and experiencing by the management organization this current situation of COVID-19 pandemic in hospitality businesses in Nueva Ecija.

\section{Objectives of the Study}

The main objective of the study was to determine the impact of Covid-19 pandemic to the hospitality business and management organization in Nueva Ecija.

Generally, the study sought to answer the following:

1. To ascertain the impact of COVID-19 pandemic in hospitality business and its management organization.

2. To determine the challenges encountered by hospitality business and its management amidst COVID-19 experienced.

3. To identify how the how the hospitality business deal in the current situation on how to manage organization.

\section{Research Problem}

This study answered the following:

1. How may the profile of the hospitality business and management organization in Nueva Ecija amidst COVID-19 pandemic be described in terms products and services, availability of supply, number of employees/staffs, work arrangement, number of operating times, number of employees working hours and mode of salary?

2. How may the hospitality business in Nueva Ecija manage cases and experiences amidst COVID-19 pandemic?

3. What is the impact of COVID-19 pandemic in hospitality business and management organization?

4. How may the hospitality business management organization deal in the current situation of COVID-19 pandemic?

\section{RESEARCH METHODS}

This research used a mixed method research designqualitative and quantitative in able to meet the objectives of the study. The respondents of the study were the selected hospitality business operators and their respective employees/staffs using purposive sampling technique. The survey and interview guide questionnaire were administered to gather the data needed. And the data gathered was analyzed with the used of statistical tools for quantitative part and logical analysis for qualitative part.

\section{RESULTS AND DISCUSSION}

2.1.1. Profile of the hospitality business and management organization in Nueva Ecija amidst COVID-19 pandemic be described in terms products and services, availability of supply, number of employees/staffs, work arrangement, number of operating times, number of employees working hours and mode of salary

Table 1, shows the profile hospitality business and management organization in Nueva Ecija in 150 respondents, found that 135 (90\%) of the respondents have no products to produce and no service operation during COVID-19 pandemic were declared locked down, thus all $150(100 \%)$ of them said that have no available supply received from the supplier. They had more than 20 employees/staffs and majority $143(95 \%)$ with working arrangements or alternate schedule of duty with 4 to 5 hours operating time. And $100 \%$ of them were changed the mode of payment into daily basis.

\begin{tabular}{|l|c|c|}
\hline \multicolumn{1}{|c|}{ Business Profile } & Frequency & Percentage (\%) \\
\hline $\begin{array}{l}\text { Product and } \\
\text { Services }\end{array}$ & 135 & 90 \\
\hline $\begin{array}{l}\text { Availability of } \\
\text { Supply }\end{array}$ & 150 & \\
\hline $\begin{array}{l}\text { No. of Employees } \\
\text { and Staffs }\end{array}$ & 143 & 95 \\
\hline $\begin{array}{l}\text { No. of Employees' } \\
\text { working hours }\end{array}$ & More than 20 & More than 20 \\
\hline $\begin{array}{l}\text { No. of Operating } \\
\text { time }\end{array}$ & 143 & 100 \\
\hline Mode of Payment & 150 & \\
\hline
\end{tabular}

\subsubsection{Hospitality business in Nueva Ecija manage cases} and experiences amidst COVID-19 pandemic

The results revealed that majority 145 (97\%) of the respondents manage cases and experiences amidst COVID-19 pandemic was used alternative working arrangement as to maintain and sustain the needs of the employees and business organization like online selling by means of creating FB page to market the product and services that the hospitality businesses in Nueva Ecija will provide. To main the number of employees as to sustain and provide their family needs, they still operated even in less minimum operating time. And to sustain the daily needs of their family the business operator/owner/manager decided to give the employees' salary in daily basis based on the scheduled of duty. One of the operators' interviews shown below:

" As the owner of this kind of business-hotel and restaurant, our income are down due to stoppage of operation, but I cannot imagine that some of my employees 
are suffering and much affected because of COVID-19, I find ways in all means even just to help them for their own families basic needs, a heartbreaking situations as you can see them that no other means to support their daily needs, so I decided to still operating in online, delivery and pick up basis, just to help them".

\subsubsection{Impact of COVID-19 pandemic in hospitality business and management organization}

One of the most affected in the COVID-19 is the locked down of all business operations especially in hospitality business and a very traumatic impact on our way of life. All $100 \%$ of the respondents said that COVID-19 pandemic affects their income with no services and product operation due to no one will go out even to buy some of their basic needs especially foods. Another thing loss of jobs and financial difficulties in all aspects of life, It is a life changing situation to all and the whole world. Majority of employees in hospitality business in Nueva Ecija especially low earners really affects their lives and experienced stress, anxiety, down physical and mental health condition and felt helpless in this tying time of global pandemic (COVID-19).

\subsubsection{Hospitality business management organization deal in the current situation of COVID-19 pandemic}

Hospitality businesses are known for giving extra and excellent assistance to those who admit under their care. They have been giving top-of-the-line services that gives theirs customers, guests, employees and staffs a high level of appreciation and thanks to the care they receive. During this trying time of the global pandemic (COVID-19), the hospitality businesses in Nueva Ecija did not stop in delivering its service, thus, out of altruism to see each of the individuals they encounter will definitely be an addition to the list of those who they enlightened the situation.

\section{CONCLUSION}

Based on the findings of the study, the following conclusions are attained.

2.2.1. The hospitality business stopped the operation especially when declared locked down, yet had no supply at all. Thus, more than 20 of their employees were affected the reason why the hospitality business needs to operate even in short time basis for continuous operation in providing basic family needs.

2.2.2. The hospitality business management organization in Nueva Ecija managed cases and experiences in COVID -19 pandemic by means of providing alternative ways as to help them their employee/staffs by providing and supporting the basic needs of the family. They use alternative working arrangements and plans for the benefits of all.

2.2.3. The global pandemic COVID 19 had a vast impact to hospitality business not only in Nueva Ecija but also worldwide in all aspects of human lives.

2.2.4. The hospitality business in Nueva Ecija never stops helping their employees in any means they can provide and also never stops sending help for others.

\section{RECOMMENDATIONS}

Based on the conclusions of the study, the researcher come up to the following recommendations:

1. The hospitality industry always think the very best in providing quality services that brings extra cares to all their employees, staffs, and customers as to maintain a good relationship and managing business organization.2. The hospitality business management organization may include health recovery in physically and mentally bases as to easily and fast recover in COVID-19 cases and experiences especially in Psychological Mental health issues.

3. The management organization in hospitality businesses always being ready in their plan of action in providing good and quality services with extra care for all customers, employees and staffs. And always follow the minimum standard protocols to prevent the spreading of COVID-19 virus. Always include mental and health program in coping mechanism for all members of the organization.

\section{ACKNOWLEDGEMENTS}

Above all, thank Lord for all your wisdom, knowledge and abundant blessings. The researcher would like to express gratitude and appreciation to those who contributed to the completion of the piece of work.

\section{REFERENCES}

[1] Kapur, Sharad (2020). Revenue and Distribution Strategies. OPINION Hospitalitynet Retrieved from Coronavirus: Impact on the Hospitality Industry - Hospitality Net Hot Topic

[2] McCarthy, J. (2020). Top Strategies for Post-Crisis Planning in Urgent Times of Wellbeing and Health. Retrieved from Top Strategies for Post-Crisis Planning in Urgent Times of Wellbeing and Health - Hospitality Net World Panel

[3] Gossling S., Scott, D. \& Hall, C.M. (2020). Pandemic, tourism and global change: a rapid assessment of COVID-19. J. Sustain.Tour 2020, pp 1-20, $10.1080 / 09669582.2020 .1758708$

[4] Nurin, T. (2020). Independent Restaurant Owners Call On Congress For Dedicated COVID-19 Aid. Forbes. Retrieved 2020-11-21

[5] Huddleston, T. (2020). How small business owners are coping with COVID-19 pandemic: "It was my civic duty to be a part of the solution". CNBC.com Retrieved from: small businesses across U.S. are coping with COVID-19 pandemic (cnbc.com)

[6] Shaffer, J. (2020). Marketing Advice for Restaurants Coping With the Covid-19 Crisis. Retrieved from Marketing Advice for Restaurants Coping with the COVID-19 Crisis | Constant Contact

[7] CFI (n.d). Management Theories. Retrieved from https://corporatefinanceinstitute.com/resources/careers/softskills/management-

theories/\#: :text=The\%20systems\%20management\%20theor $y \% 20$ proposes $\% 20$ that $\% 20$ businesses $\% 2$ C\%20like,elements $\% 3 A \% 20$ synergy\%2C\%20interdependence\%2C\%20and\%20i nterrelations\%20between\%20various\%20subsystems.

[8] Follard, A. (2020). A unified theory of happiness. Twitter, Facebook and LinkedIn 
[9] Psychology Today.4 Coping Mechanism of Covid-19. Retrieved from: 4 Coping Mechanisms for COVID-19 | Psychology Today

[10] Bingham, R.S. \& Hariharan, K, (2020). Corona Virus Expected to Impact to Tech Industry Shipment. World Economic Forum. Retrieved from: This is the impact of the Coronavirus on business | World Economic Forum (weforum.org) 